\title{
The Influence of External Contingency Factors and Activity-Based Costing Implementation on Organizational Performance
}

\author{
(Pengaruh Faktor Kontingensi Luaran dan Pelaksanaan Pengkosan Berasaskan Aktiviti ke atas \\ Prestasi Organisasi)
}

\author{
Faeq Malallah Mahmood Albalaki \\ (College of Administration and Economics, Mosul University) \\ Zarifah Abdullah \\ Hasnah Kamardin \\ (Tunku Puteri Intan Safinaz School of Accountancy, Universiti Utara Malaysia)
}

\section{ABSTRACT}

The Activity-Based Costing $(A B C)$ system continues to gain attention due to the increasing challenges in the current business environment. This situation motivated the researchers to examine external contingency factors (environmental uncertainty (EU) and market orientation (MO)) that influence ABC implementation and the possible effects of ABC implementation on organizational performance. This study also examines the mediating effect of ABC implementation on the relationship between external contingency factors and organizational performance in a developing economy. A cross-sectional survey was conducted among 114 manufacturing companies in Iraq. The data was analyzed using PLS3-SEM, and the results revealed that $E U$ and $M O$ have a positive and significant effect on $A B C$ implementation, and that ABC implementation has a positive and significant effect on organizational performance. Furthermore, this study establishes the mediating role of ABC implementation on the relationship between external contingency factors and organizational performance.

Keywords: ABC implementation; contingency factors; organizational performance; Iraq

\section{ABSTRAK}

Sistem Pengkosan Berasaskan Aktiviti (ABC) terus mendapat perhatian disebabkan oleh peningkatan cabaran dalam persekitaran perniagaan semasa. Keadaan ini telah mendorong para penyelidik untuk mengkaji faktor-faktor kontingensi luaran (ketidakpastian persekitaran (EU) dan orientasi pasaran (MO)) yang mempengaruhi pelaksanaa ABC dan kesan mungkin pelaksanaan ABC terhadap prestasi organisasi. Kajian ini juga memeriksa kesan mediasi pelaksanaan ABC ke atas hubungan antara faktor kontingensi luaran dan prestasi organisasi dalam ekonomi yang sedang membangun. Satu kajian selidik telah dijalankan di kalangan 114 syarikat pembuatan di Iraq. Data tersebut dianalisis dengan menggunakan PLS3SEM dan hasilnya menunjukkan bahawa EU dan MO mempunyai kesan yang positif dan signifikan terhadap pelaksanaan $A B C$, dan pelaksanaan ABC tersebut mempunyai kesan yang positif dan signifikan terhadap prestasi organisasi. Tambahan pula, kajian ini membuktikan peranan mediasi pelaksanaan ABC terhadap hubungan antara faktor-faktor kontingensi luaran dan prestasi organisasi.

Kata kunci: Pelaksanaan ABC; faktor-faktor kontingensi; prestasi organisasi; Iraq.

\section{INTRODUCTION}

Changes in the competitive environment and structure of organizations affect their performances (Kalkan, Erdil \& Çetinkaya 2011), and concomitantly stimulate such organizations to change their management accounting (MA) practices in order to achieve a better fit with these changes (Cescon, Costantini \& Grassetti 2018). As such, the implementation of the $\mathrm{ABC}$ system for generating accurate costing information and making effective decisions to improve organizational performance in today's advanced and highly competitive manufacturing environment continues to receive momentous attention from both practitioners and researchers (Cinquini et al. 2015; Sorros, Karagiorgos \& Mpelesis 2017).

Employing the theoretical perspective of the contingency theorists, the particular feature of an appropriate cost accounting system depends on the specific circumstances within and outside an organization (Tillema 2005). Studies in the realm of MA literature have affirmed that environmental uncertainty (EU) and market orientation (MO) are essential contingency factors that can determine the success of MA techniques used by an organization (Gliaubicas \& Kanapickienè 2015; Anderson \& Young 1999; Laitinen 2014). Also, MA techniques, such as the ABC system, are crucial for companies to cope with different challenges, while also providing astute information that does not only help in overcoming the challenges of changes in a business environment, but also help in improving organizational performance (Baines \& Langfield-Smith 2003). While previous $\mathrm{ABC}$ studies have examined the relationships among competitive strategies, information technology, $\mathrm{ABC}$ implementation and organizational performance 
(Frey \& Gordon 1999; Maiga, Nilsson \& Jacobs 2013), there has only been little empirical evidence on whether organizational performance is influenced by EU, MO and ABC implementation. Zaman (2009) affirmed that the extant body of knowledge has left an apparent gap in measuring the perception of $\mathrm{ABC}$ and the impact of its implementation on overall organizational performance. Elhamma (2015) reported that previous MA studies have tested EU in the context of innovativeness, other than the ABC system. Also, Cadez and Guilding (2008) argued that MO has not been widely studied and should be considered as an added contingency factor. Therefore, this study fills these gaps in current $\mathrm{ABC}$ research.

The results reported in previous studies on EU (Uyar \& Kuzey 2016; Rivard, Raymond \& Verreault 2006) and MO (Noble, Sinha \& Kumar 2002; Ismail, Isa \& Mia 2018b) are inconclusive. One of the possible reasons for these inconclusive results is that managers' use of MA information, such as $\mathrm{ABC}$ information, may mediate this relationship (Ismail, Isa \& Mia 2018a) Mat and Smith (2014) echoed that understanding the mediating effect of advanced MA practices such as $\mathrm{ABC}$ implementation on the relationship between contingency factors and organizational performance is considered an important research area. Frazier, Tix and Barron (2004) argued that a mediating variable is required to explain and enhance the relationship between the independent variable (external contingency factors) and the dependent variable (organizational performance). This implies that the implementation of $\mathrm{ABC}$ by Iraqi manufacturing companies is motivated by the imprecision in determining costs and control pitfalls, as well as lack of rationalizing decisions resulting from the use of traditional cost systems. Furthermore, the results of the traditional cost systems impacted negatively on the performance of the Iraqi manufacturing companies (Youssef \& Oudah 2014). However, previous studies have shown that the implementation of $\mathrm{ABC}$ influences organizational performance in so many ways, such as reducing the effect of EU and intense competition (Gupta \& Galloway 2003). Despite these facts, evidences on how ABC implementation has contributed to the relationship between contingency factors and organizational performance are scarce in developing economies.

Conversely, Cadez and Guilding (2008) were unable to support the mediation effect of strategic MA usage, including an activity-based approach to the relationship between MO and organizational performance. Hoque (2004) found no evidence of a mediating role of non-financial performance measures between EU and organizational performance. In order to address the highlighted gaps, the following objectives are set out:

1. To examine whether EU and MO have significant effects on $\mathrm{ABC}$ implementation.

2. To examine whether EU and MO have significant effects on organizational performance.

3. To investigate the effect of $\mathrm{ABC}$ implementation on organizational performance.
4. To determine whether $\mathrm{ABC}$ implementation plays a mediating role on the relationship between external contingency factors and organizational performance.

The remainder of this paper presents a section on literature review, where the key variables were operationally defined and explained, followed by a section on research framework and hypotheses development. This is followed by a section on methods and a section on analysis, which includes subsections on measurement, structural models and results of the mediation effect. The final sections are dedicated to the discussion and conclusion, where the findings, implications, limitations and recommendations are discussed in detail.

\section{LITERATURE REVIEW}

The $\mathrm{ABC}$ system refers to a costing approach that itemizes activities as the significant objects of costing. This approach uses a cost driver as the basis for allocating cost to different cost objects such as products, services and customers (Anderson \& Young 1999). Consistent with prior $\mathrm{ABC}$ adoption research (Anderson \& Young 1999; Byrne 2011), the definition of the implementation of $\mathrm{ABC}$ in this study refers to the operating units that are currently using $\mathrm{ABC}$ systems in their organizations. Previous studies (e.g. Cinquini et al. 2015; Lu et al. 2017) provided empirical evidence on the use of the $A B C$ system in different aspects, such as for cost reduction, for planning and controlling organizational activities, and for improving organizational performance. However, prior ABC-based studies conducted in Iraq have been limited in two ways. First, some of these studies (e.g. Farhood 2005; Yaqoob \& Bachay 2017) concentrated on the early version of $\mathrm{ABC}$ as a full costing system. Thus, other potential benefits of $\mathrm{ABC}$ that could be developed in practice are largely ignored in these studies. Second, there has been a lack of investigation on the functionality and compatibility issues of $\mathrm{ABC}$ systems. For instance, quantitative studies (e.g. Cadez \& Guilding 2008; Jusoh \& Miryazdi 2015) attempted to link EU and MO with the $\mathrm{ABC}$ system, but evidence of this kind of research in Iraqi manufacturing companies is scarce.

Buchko (1994) defined EU as the inability of an individual to predict an organization's environment accurately because of a lack of information, or an inability to discriminate between relevant or irrelevant data. That is, a higher level of uncertainty increases companies' need to get more information, including cost information with emphasis on advanced costing system (Ajibolade 2013). However, Jusoh and Miryazdi (2015) argued that the prior contingency studies such as Chenhall and Morris (1986) and Anderson and Young (1999) provided conflicting evidences on the condition of external environments affecting costing systems, particularly the implementation of $\mathrm{ABC}$ in organizations. As such, there is an urgent need to conduct further studies in this regard. 
MO, on the other hand, is defined as the culture of an organization in implementing marketing activities, which requires that customer satisfaction be put at the center of business operations, and therefore produces superior value for customers better than competitors, and thus engenders outstanding performance for the organization (Han, Kim \& Srivastava 1998). This study focuses on three facets of MO (Narver \& Slater 1990); (1) customer orientation, (2) competitor orientation and (3) interfunctional coordination. When MO activities are deployed individually, they are more likely to be less effective. In other words, when an organization relies exclusively on customer orientation, this can result in an imbalance of strategy, which leaves the organization reactive rather than proactive towards competitors' strategies (Han et al. 1998). Similarly, when organizations focus more on their competitors, they can end up neglecting their valuable customers (Day \& Wensley 1988). As a result of these, Narver and Slater (1990) proposed a balanced deployment of market strategies between customers' and competitors' orientations, as well as inter-functional coordination. The debate on whether MO is a contingency factor to the strategic $\mathrm{MA}$ or the implementation of $\mathrm{ABC}$ being an innovative strategy is still ongoing in the literature (Naranjo-Gil 2009). Hence, there is a need to understand the significance of $\mathrm{MO}$ on the implementation of $\mathrm{ABC}$ (Abdel-Kader \& Luther 2008).

Notably, organizational performance is influenced by EU, MO and MA system. Kaplan (2001) puts forth the argument that it is unanimously acceptable among strategic MA researchers to use both financial and non-financial constructs for measuring organizational performance. The benefit of combining financial and nonfinancial performance measurements is to concurrently assess organizational improvements in all the important areas such as products, profits, operations, customers, and market growth (Baines \& Langfield-Smith 2003). Some empirical evidences have proved the theoretical argument of a positive association among EU, MO, and organizational performance (Uyar \& Kuzey 2016; McManus 2013). In contrast, no association among EU, MO and organizational performance is documented (Houqe 2004; Zhou, Brown $\&$ Dev 2009). In view of the mixed findings in the current literature, this study is therefore motivated to re-examine the relationship among EU, MO and organizational performance.

Though previous studies (e.g. Lee et al. 2010; Zaman 2009) have exerted significant efforts in understanding the direct relationship between $\mathrm{ABC}$ and performance, only few studies, such as Frey and Gordon (1999) and Ittner, Lanen and Larcker (2002), have considered the mediating role of $\mathrm{ABC}$ on the relationship between organizational factors and performance. In addition, previous studies (e.g. Cadez \& Guilding 2008; Mia 1993) typically focused on the mediating effect of the MA system on the relationship between external contingency factors and performance, while only little attention has been given to the mediating effect of $\mathrm{ABC}$ implementation. As such, Jänkälä and Silvola (2012) stressed that further examinations are needed to investigate how contingency factors affect the use of $\mathrm{ABC}$ and the subsequent emergence of performance. Thus, this study attempts to bridge these apparent gaps in prior research, by contributing to our understanding of contingency factors, $\mathrm{ABC}$ implementation and organizational performance in Iraq.

\section{RESEARCH FRAMEWORK AND HYPOTHESES DEVELOPMENT}

This study adopts a Cartesian type with a mediation model under the contingency approach (Chenhall 2003; Gerdin \& Greve 2004). The purpose of employing the contingency approach and precisely the mediation model is to determine the equal influence of external contingency variables (e.g. EU and MO) and structural variables (e.g. $\mathrm{ABC}$ implementation) on improving and enhancing organizational performance (e.g. financial and nonfinancial performance) among manufacturing companies in Iraq. Based on this theoretical foundation, the following relationships are discussed and predicted.

\section{ENVIRONMENTAL UNCERTAINTY AND ABC IMPLEMENTATION}

McManus (2013) argued that detailed information on the complexity of the external environment is paramount to the successful implementation of sophisticated MA techniques. The findings reported by Innes and Mitchell (1990) concurred with this, as demonstrated in a case study research on how changes in the business environment motivate the implementation of ABC. Furthermore, Arnaboldi and Lapsley (2005) hold that the more information at the disposal of an organization on the condition of its external environment, the more accurate their cost information, which by extension, improves the accuracy of the organizations' cost management system. Similarly, Naranjo-Gil (2009) revealed that there is a positive relationship between technological innovations and EU. Elhamma (2015) found that EU has a significant and positive impact on the use of the $\mathrm{ABC}$ system. A contingency-based model is proposed, such that greater emphasis on sophisticated MA techniques is associated with organizations facing high uncertainty (Govindarajan 1984). In the light of this fact, and particularly in the wake of the persistent political and economic uncertainties currently in Iraq, this study formulates the following hypothesis:

$\mathrm{H}_{1}$ Environmental uncertainty has a positive effect on $\mathrm{ABC}$ implementation. 


\section{MARKET ORIENTATION AND ABC IMPLEMENTATION}

One of the most commonly raised questions is whether market-oriented organizations are influenced by either customer, competitor or inter-functional factors to implement MA techniques, hence, the need to understand the significance of $\mathrm{MO}$ on the implementation of the $\mathrm{ABC}$ system (Cadez \& Guilding 2008; Abdel-Kader \& Luther 2008). The current intense competition in the modern and globalized business environment has heightened the importance of customers and accurate information about customers (Juhdi, Hong \& Juhdi 2015). Notably, MO may motivate ABC usage. For instance, Bromwich (1990) reported that one of the strong reasons that urged organizations to increased adoption of strategic MA techniques is MO. Guilding and McManus (2002) suggested that $\mathrm{ABC}$ is applicable when the customer is the unit of analysis. Liu and Pa (2007) demonstrated that market and customer orientations produce successive changes in activities, while cost drivers led to the adoption of the $\mathrm{ABC}$ system to meet customers' needs and to overcome competitors. Yapa and Kongchan (2012) found that the changes in customer behavior, due to pricing competition, have a considerable influence on $\mathrm{ABC}$ implementation. The contingency theory assumes that strategic MA systems such as $\mathrm{ABC}$ are functions of environmental factors, including MO (Cadez \& Guilding 2008). Furthermore, contingencybased studies have demonstrated that there is a strong and positive relationship between MO and innovativeness or ABC implementation (Gliaubicas \& Kanapickienè 2015; Guilding \& McManus 2002). Given these, the current study proposes the following hypothesis:

$\mathrm{H}_{2}$ Market orientation has a positive and significant effect on $\mathrm{ABC}$ implementation.

\section{ABC IMPLEMENTATION AND ORGANIZATIONAL PERFORMANCE}

The aim of implementing $\mathrm{ABC}$ across organizations is primarily to perfect cost analysis and influence the decision-making process with a view to enhancing and improving organizational performance (Sorros et al. 2017). Evidently, studies have reported that the use of modern MA techniques such as the ABC system can enhance organizational performance, particularly in the manufacturing sector (Cinquini et al. 2015; Qian \& BenArieh 2008). For instance, Lu et al. (2017) demonstrated that the implementation of $\mathrm{ABC}$ has contributed greatly to increasing organizations' profitability and competitive power. Other studies conducted by Cagwin and Bouwman (2002) and Maiga and Jacobs (2003) indicated that ABC is a strategic MA system with functionalities that improve return on investment and provide accurate profitability analysis. Also, the empirical results from 100 responses collected by Lee et al. (2010) demonstrated that the level of $A B C$ usage is significantly correlated with financial and non-financial performance improvement. A similar finding was reported from an explanatory study conducted by Zaman (2009) in Australia. Based on previous contingency studies, there is a significant positive and strong correlation between $\mathrm{ABC}$ implementation and organizational performance (Chenhall \& Langfield-Smith 1998; Fei \& Isa 2011; Kennedy \& Affleck-Graves 2001). In the light of this fact, and particularly the current unimpressive performance of Iraqi manufacturing companies, the current study expects that $\mathrm{ABC}$ implementation would enhance the performance of Iraqi manufacturing companies.

$\mathrm{H}_{3} \quad$ ABC implementation success has a positive effect on organizational performance.

\section{ENVIRONMENTAL UNCERTAINTY AND ORGANIZATIONAL PERFORMANCE}

Contingency theorists have posited that the necessary effect of uncertainty is to limit the ability of the organization to pre-plan or make decisions about the activities of their operations in advance of execution. Hence, when the environment becomes highly uncertain, it limits the preparation and execution of organizations and subsequently affects organizational performance (Govindarajan 1984). Jusoh (2008) found that EU has a significant negative correlation with organizational performance. Köseoglu et al. (2013) found that EU has a partial significance on organizational performance. Their findings are consistent with the conclusion presented by Kotha and Nair (1995) with regard to the significant impact of EU on firm profitability. However, other studies have demonstrated that EU has no significant impact on organizational performance (Houqe 2004; Rivard et al. 2006). Mia (1993) revealed that there is no association between EU and organizational performance. The results indicated that the MA system mediates this relationship. It is now more critical than ever to understand the connection between EU and organizational performance further, the reason being that the current global market is increasingly becoming uncertain (Soheilirad \& Sofian 2016). Thus, the following hypothesis is predicted:

$\mathrm{H}_{4}$ Environmental uncertainty has a negative effect on organizational performance.

\section{MARKET ORIENTATION AND ORGANIZATIONAL PERFORMANCE}

Numerous researchers have attempted to establish the various levels of relationship that connect MO and organizational performance. Meanwhile, far little studies have been able to provide statistical or rather empirical evidence as to how MO leads to an improvement in organizational performance (Hunt \& Lambe 2000; Narver \& Slater 1990). O'Cass and Viet Ngo (2007) employed a structural equation modelling (SEM) approach to test 
the relationship between MO and brand performance statistically. Their findings demonstrated that MO is a subset of organizational culture, which leads to improvement in brand performance. Low, Chapman and Sloan (2007) measured MO with three constructs; customer orientation, competitor orientation and inter-functional coordination. It was reported that the three constructs of MO are significantly and positively related to organizational performance. The interpretation of these findings is that MO is a type of organizational culture that leads to an improvement in organizational performance. The results of previous researchers (Cadez \& Guilding 2008; McManus 2013; Slater \& Narver 2000) showed a strong positive relationship between MO as a contingency factor and organizational performance. Meanwhile, other studies reported that MA information, innovation or learning significantly influence the relationship between MO and organizational performance (Noble et al. 2002; Han et al. 1998; Zhou et al. 2009). However, Iraqi manufacturing companies need to be continuously alert of the challenges in the global market. Therefore, MO is fundamental to enhancing the performance of Iraqi companies. As such, the present study hypothesizes that:

$\mathrm{H}_{5}$ Market orientation has a positive and significant effect on organizational performance.

\section{EXTERNAL CONTINGENCY FACTORS, ABC IMPLEMENTATION AND ORGANIZATIONAL PERFORMANCE}

From a survey of 90 Australian manufacturing companies, Mia and Clarke (1999) found that MAS plays a mediating role between the intensity of market competition and business unit performance. Meanwhile, Chong and Chong (1997) conducted a study among 62 managers in manufacturing companies in Western Australia. Their findings demonstrated that there is a significant but indirect effect of EU on organizational performance through MA information. Han et al. (1998) empirically demonstrated that MO facilitates innovations, such as $\mathrm{ABC}$, in organizations, which in turn positively influence their business performance. The study by Cagwin and Bouwman (2002) found that competitive environments influence the efficacy of the $\mathrm{ABC}$ system, when $\mathrm{ABC}$ is implemented to improve financial performance. In addition, a significant relationship between market competition and organizational performance with the mediating effect of MA systems change - including ABCwas presented by Hoque (2011).

These arguments are in line with the theoretical perspectives of the contingency theory, which advocate that organizational performance requires fit between the use of MA techniques and contextual variables (Chenhall 2003; Hoque 2004; Mia 1993). However, it was noted that very little studies have explored the mediating effect of $\mathrm{ABC}$ implementation in the relationship between external contingency factors and organizational performance in developing countries (Elhamma 2015). In particular, no relevant evidence exists in Arab countries. Therefore, it is expected to further this longstanding argument by examining the mediating role of $\mathrm{ABC}$ implementation on the relationship between external contingency variables and organizational performance. Following these arguments, this study proposes the following hypotheses:

$\mathrm{H}_{6} \quad \mathrm{ABC}$ implementation mediates the relationship between environmental uncertainty and organizational performance.

$\mathrm{H}_{7} \quad \mathrm{ABC}$ implementation mediates the relationship between market orientation and organizational performance.

Accordingly, the theoretical framework of this study is presented in Figure 1 below. The framework relies on the contingency theory and the results of previous studies to depict the relationship between $\mathrm{EU}, \mathrm{MO}, \mathrm{ABC}$ implementation and organizational performance.

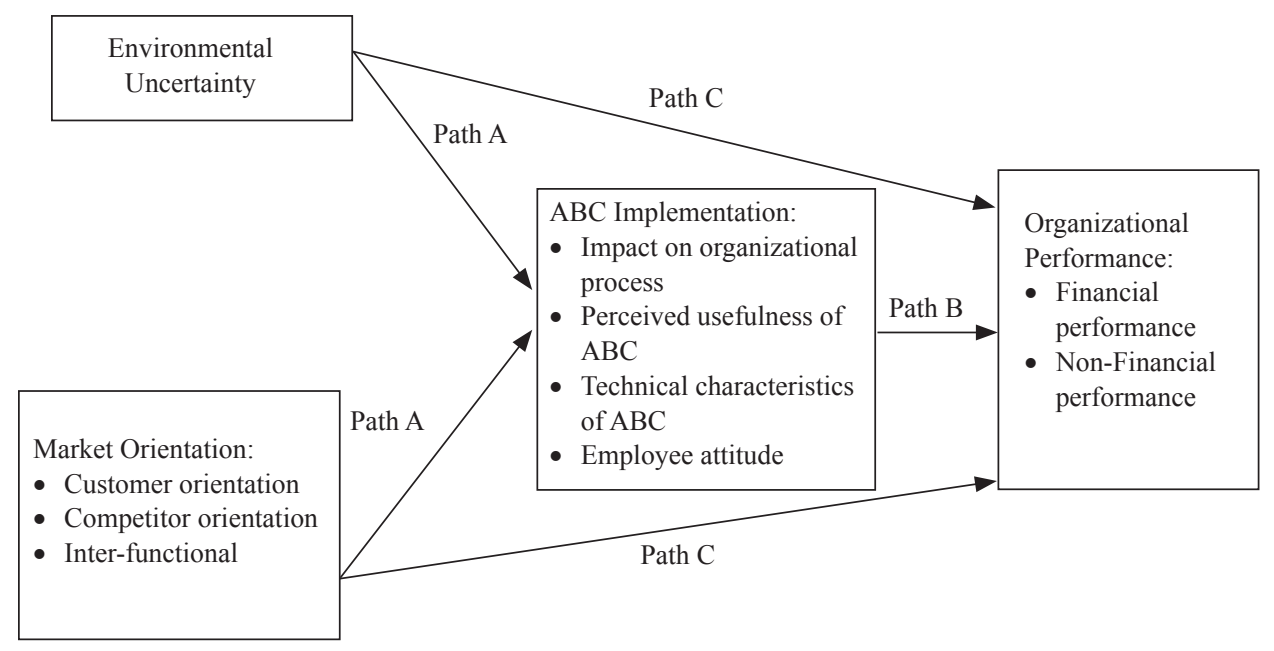

FIGURE 1. Theoretical framework 


\section{METHOD}

The population of this study is a select group of manufacturing companies in Iraq. Specifically, it focuses on large industrial manufacturing companies in Iraq. The target sample was selected because they are more likely to adopt and implement the $\mathrm{ABC}$ system according to Innes and Mitchell (1990). According to the Iraqi Central Statistical Organization (SCO) (2015), there are 707 large industrial manufacturing companies in Iraq. Using the sample size table generated by Krejcie and Morgan (1970) for a given population of 700 and above, a sample size of 248 would be required to represent the population of this study. Previous studies on ABC conducted in Iraq have recorded quite high response rates. For instance, a $78 \%$ response rate was recorded in the study conducted by Jaf, Sabr and Nader (2015) and a $84.44 \%$ rate was recorded in the study conducted by Al-Zaidy (2010). On this basis, this study requires a distribution of around 305 forms in order to obtain the required sample size. The sampling technique adopted for selecting the sample size from the population is the simple random sampling technique. The researchers adopted the use of survey questionnaires that were handdelivered by the researchers and hired enumerators to the offices of the respondents. This method was chosen because of the lack of reliable postal services in Iraq, which makes it unadvisable to use a mail questionnaire. The data collection lasted for 4 months and one week, from $1^{\text {st }}$ of March 2017 till $7^{\text {th }}$ of July, 2017, and the researchers obtained 239 completed questionnaires. This represents a $78 \%$ response rate.

The data was collected from the Chief Financial Officers (CFOs) within the sample companies. However, the CFOs were asked whether anybody else (e.g. Financial Controller) was appropriate to complete the questionnaire, in which case it could be passed to them. In addition, Zhang, Hoque and Isa (2015) assumed that for companies without a CFO or Financial Controller, the Finance Manager would be the appropriate respondent. The CFO, Financial Controller and Fnance Manager are considered appropriate to answer the research questionnaire because they have explicit knowledge and sufficient expertise for implementing $\mathrm{ABC}$ and understand the circumstances regarding external contingency factors that might affect the implementation of $\mathrm{ABC}$ and overall performance in their companies (Ismail et al. 2018b; Zhang et al. 2015). Generally, organizational researchers on quantitative research often employ the survey method, as it is considered the most appropriate method for collecting information on predetermined instruments that yield statistical data on a large sample to generalize the result (Creswell 2009). For analysis purposes, the SEM was employed for both measurement analysis and hypotheses testing using partial least squares (PLS3) path modelling (Hair et al. 2014).

Nineteen items were adopted and modified based on the published items of McGowan (1998) to measure $\mathrm{ABC}$ implementation in this study. The items focused on four groups of dimensions of $\mathrm{ABC}$ implementation; impact on the organizational process (measured with 6 items), perceived usefulness of $\mathrm{ABC}$ (measured with 5 items), technical characteristics of $\mathrm{ABC}$ (measured with 4 items) and employee attitude (measured with 4 items). The reason for using a multidimensional measure was to avoid the measurement bias that may appear in the use of a single dimension (Rahmouni \& Charaf 2010). The dimensions used in the current study are the same as those used by McGowan. However, McGowan's study is based on preparers' and users' perceptions of $\mathrm{ABC}$ implementation. Nevertheless, the results of McGowan's (1998: 46) study affirmed that preparers (or designers) and users mostly "view the implementation of ABC similarly, because designers of the system key very strongly on how successful they believe users perceived the project to be." For this reason, and consistent with the definition of $\mathrm{ABC}$ implementation given in the introduction section, the current study is based only on ABC users.

Organizational performance was measured with eight (8) items for both financial and non-financial performance, which was adapted from Govindarajan (1984). Consistent with Fei and Isa (2011), the items required respondents to rate both the financial and non-financial performance of their organizations, as compared to their industry in the past three years. Furthermore, eight items were adapted from Hoque (2004) for measuring EU in the current study. Finally, fifteen (15) items were adapted from Narver and Slater (1990) for measuring MO with three dimensions; customer orientation (measured with six items), competitor orientation (measured with four items) and inter-functional coordination (measured with five items). The seven-point Likert-type scale (ranging from 1 to 7) was used to anchor the responses of the respondents for all the variables.

\section{ANALYSIS}

Three questions (Yes/No answers) were used to distinguish between the $\mathrm{ABC}$ implementer groups and non- $\mathrm{ABC}$ implementer groups: (1) Non-implementation of $A B C$ at all, (2) $\mathrm{ABC}$ implementation is used for activity cost analysis, and (3) $\mathrm{ABC}$ implementation is used for measuring product cost and for decision-making purposes. The descriptive analysis revealed that 127 respondents are from the organizations which have implemented $\mathrm{ABC}$ , either at the activity cost analysis level, the measuring product cost and decision-making purposes level, or both. The remaining 112 respondents, who were from firms that have yet to implement $\mathrm{ABC}$, are excluded from this study. However, of the 127 usable respondents, 4 respondents were omitted during the assessment of outliers, and 9 respondents were unusable and excluded from further analysis. Hence, only 114 usable respondents were retained for this study.

Both SPSS and PLS3 were employed to analyze the data collected for this study. SPSS was used to effectuate the preliminary analysis, including descriptive statistics, 
normality, outlier and multicollinearity. The descriptive findings presented in Table 1 revealed that majority $(52.6 \%)$ of the respondents in this study are CFOs. This is followed by $22.8 \%$ who are Financial Managers and $15.8 \%$ who are Financial Controllers. Only $8.8 \%$ of the respondents are others who are holding the positions related to either cost or management accounting. In addition, the majority of the respondents (46.4\%) have worked in their current organization for more than 12 years. This is expected, as the respondents in this study are highly ranked managers and officers. $29.8 \%$ of the respondents have 4 to 8 years working experience with their current organization. It was also observed that $14.9 \%$ of the respondents have 9 to 12 years of working experience with their organizations. Meanwhile, $5.2 \%$ of the respondents have the lowest working experience, in the range of less than 4 years.
Table 1 also reveals that $101(88.6 \%)$ respondents are from organizations that have been established for more than 6 years. $12(10.5 \%)$ respondents are from manufacturing organizations founded between 3 to 6 years ago, while there was no organization founded under less than 3 years ago. These distributions suggest that majority of the respondents are from organizations which have been established for more than three years, which is enough time to reflect on the performance of their organizations. The results of comparative analysis (t-tests) confirmed that the variances are homogeneous between the early and late respondents, who indicated no significant difference between the two groups, as the equality of the mean responses of both groups were not significant. Therefore, these results suggest no issue of response bias in the data of this study.

TABLE 1. Descriptive information

\begin{tabular}{llcc}
\hline Demographic Variables & \multicolumn{1}{c}{ Category } & Frequency & Percent $(\%)$ \\
\hline \multirow{2}{*}{ Position } & Chief Financial Officer & 60 & 52.6 \\
& Financial Manager & 26 & 22.8 \\
& Financial Controller & 18 & 15.8 \\
& Others & 10 & 8.8 \\
Years of working in the organization & Below 4 years & 6 & 5.2 \\
& 4-8 years & 34 & 29.9 \\
& 9-12 years & 17 & 4.0 \\
Age of organization & Above 12 years & 53 & 3.5 \\
& Missing & 4 & 10.5 \\
& 3-6 years & 12 & 88.6 \\
\hline
\end{tabular}

$\mathrm{n}=114$

The researchers designed the model in the PLS-SEM analysis based on the theoretical framework presented in Figure 1. The PLS-SEM analysis allows for the conceptualization of a hierarchical model through the recurrent use of manifest variables (Lohmöller 1989). As such, the current study adopts the Hierarchical Components Model (HCM). Typically, HCM consists of two layers: the Higher-Order Construct (HOC) and LowerOrder Constructs (LOCs). Specifically, the HOC is a central construct and is usually related to two or more LOCs. This means that the LOCs represent the sub-dimensions of the HOC (Hair et al. 2014). According to Hair et al. (2014), the most important reason for employing HCM is to ensure easier understanding of both the measurement and structural models and to avoid collinearity issues. The variables understudied in this research are operationalized as a reflective-reflective type of $\mathrm{HCM}$, consisting of four HOCs (ABC implementation, EU, MO and organizational performance) and nine LOCs; which are the dimensions of $\mathrm{ABC}$ implementation (4), organizational performance (2) and MO (3). The assessment of the measurement model (HOCs and LOCs) involves a series of activities, such as determining internal consistency reliability, examining indicator reliability, and finally, assessing the convergent and discriminant validity (Hair et al. 2014). The essence of these activities is to collectively establish the relationship between the observed variables and the latent variables. The results of both the measurement and structural models are reported in the following subsections.

\section{MEASUREMENT MODEL}

The reliability and validity of the LOCs (first-order model) were assessed by the measurement model of PLS3 path modelling. This model has been used frequently by MA researchers (e.g. Hoque 2011; Laitinen 2014). PLS3 is useful when the theory sets out to explain the effect of variables that intervene in relationships between independent variables and dependent variables (Hair et al. 2014). As shown in Table 2, the internal consistency reliability has been achieved for all reflective constructs as represented by Cronbach Alpha and Composite Reliability, which is above the threshold of 0.60 and 0.70 (Hair et al. 2014) for all variables respectively. The Average Variance Extracted (AVE) of the reflective 
TABLE 2. Outer loadings, Cronbach's Alpha, Composite Reliability and AVE for the LOCs

\begin{tabular}{|c|c|c|c|c|}
\hline Constructs and Items & Loadings & Cronbach's Alpha & Composite Reliability & AVE \\
\hline \multicolumn{5}{|l|}{ ABC implementation success (ABC) } \\
\hline Impact on organization process (IOP) & & 0.821 & 0.870 & 0.527 \\
\hline Quality of decision & 0.747 & & & \\
\hline Efficiency and waste reduction & 0.689 & & & \\
\hline Innovation & 0.762 & & & \\
\hline Relationship across functions & 0.715 & & & \\
\hline Communication across functions & 0.725 & & & \\
\hline Overall goal of the organization & 0.716 & & & \\
\hline Perceived usefulness of ABC (PUA) & & 0.755 & 0.837 & 0.509 \\
\hline Operations control & 0.673 & & & \\
\hline Accomplishment of task more quickly & 0.760 & & & \\
\hline Enhancement of effectiveness & 0.744 & & & \\
\hline Making jobs easier & 0.777 & & & \\
\hline Usefulness on my job entirely & 0.600 & & & \\
\hline Technical characteristic (TC) & & 0.833 & 0.888 & 0.666 \\
\hline Accurate information & 0.809 & & & \\
\hline Accessible information & 0.790 & & & \\
\hline Reliable information & 0.836 & & & \\
\hline Timely information & 0.827 & & & \\
\hline Employee attitude (EA) & & 0.896 & 0.928 & 0.762 \\
\hline Favorable attitude & 0.893 & & & \\
\hline Embrace ABC & 0.863 & & & \\
\hline Willingness to use $\mathrm{ABC}$ & 0.877 & & & \\
\hline Easy to incorporate $\mathrm{ABC}$ system & 0.858 & & & \\
\hline \multicolumn{5}{|l|}{ Organizational performance (OP) } \\
\hline Financial (FP) & & 0.858 & 0.904 & 0.702 \\
\hline Level of firm profitability & 0.850 & & & \\
\hline Sales and revenues & 0.889 & & & \\
\hline Return on investment & 0.822 & & & \\
\hline Operational and cost efficiency & 0.788 & & & \\
\hline Non-financial (NFP) & & 0.832 & 0.888 & 0.665 \\
\hline Market share & 0.846 & & & \\
\hline Customer loyalty & 0.852 & & & \\
\hline Employee satisfaction & 0.758 & & & \\
\hline $\mathrm{R}$ and $\mathrm{D}$ activities & 0.804 & & & \\
\hline Environmental uncertainty (EU) & & 0.881 & 0.904 & 0.544 \\
\hline Suppliers' actions & 0.584 & & & \\
\hline Customer demands and tastes & 0.686 & & & \\
\hline Market activities of competitors & 0.764 & & & \\
\hline Government regulation and policies & 0.712 & & & \\
\hline Economic environment & 0.813 & & & \\
\hline Production and IT & 0.775 & & & \\
\hline Stability of environment & 0.773 & & & \\
\hline Industrial relations & 0.769 & & & \\
\hline \multicolumn{5}{|l|}{ Market orientation (MO) } \\
\hline Customer orientation (CUO) & & 0.782 & 0.852 & 0.536 \\
\hline Create customer value & 0.786 & & & \\
\hline Information about customers is freely communicated & 0.788 & & & \\
\hline Understanding customers' needs & 0.741 & & & \\
\hline Customer satisfaction & 0.691 & & & \\
\hline Measuring customer satisfaction & 0.644 & & & \\
\hline Competitor orientation (COO) & & 0.765 & 0.849 & 0.585 \\
\hline $\begin{array}{l}\text { Top management regularly discusses competitors' strength } \\
\text { and weaknesses }\end{array}$ & 0.764 & & & \\
\hline $\begin{array}{l}\text { Competitive advantage is based on understanding target } \\
\text { opportunities }\end{array}$ & 0.807 & & & \\
\hline Rapidly respond to competitive actions & 0.733 & & & \\
\hline Salespeople share competitor information & 0.754 & & & \\
\hline Inter-functional coordination (IFC) & & 0.766 & 0.842 & 0.516 \\
\hline Business functions are integrated to serve the target market needs & 0.719 & & & \\
\hline Managers understand how employees can contribute to value & 0728 & & & \\
\hline Inter-functional customer calls & 0.765 & & & \\
\hline Information shared among functions & 0.721 & & & \\
\hline Share resources with other business units & 0.656 & & & \\
\hline
\end{tabular}


dimensions is higher than 0.50 , indicating that the convergent validity is established and the convergent validity of reflective constructs is also achieved. Furthermore, the loadings of the items measuring the dimensions (indicator reliability) range between 0.58 and 0.89 . However, only one item with loadings below 0.50 was eliminated from the model.

Additionally, to ascertain the discriminant validity of the reflective constructs for LOCs, the square root of AVE of each dimension should be higher than its correlations with any other construct (Fornell \& Larcker 1981). As shown in Table 3, the diagonal bolded values represent the square root of AVE, which is above the correlation of any reflective variable with another. This indicates that the discriminant validity is established at LOCs.

To assess the second stage HOCs, the latent variable scores in the first order model (LOCs) were recomputed in the second stage HOM. As a result, the dimensions of the constructs in the first stage model served as items for the constructs in the second stage model (Henseler 2007). The result of the second stage, which is the hierarchical measurement model, revealed that the second order model (Table 4) is fit, as the Cronbach's Alpha, Composite Reliability and AVE values are all above the expected threshold of $0.60,0.70$ (Hair et al. 2014) and 0.50 respectively (Chin 1998).

TABLE 3. Discriminant validity for first stage hierarchical construct model

\begin{tabular}{|c|c|c|c|c|c|c|c|c|c|c|}
\hline & $\mathrm{COO}$ & CUO & EA & EU & FP & IFC & IOP & NFP & PUA & $\mathrm{TC}$ \\
\hline $\mathrm{COO}$ & 0.765 & & & & & & & & & \\
\hline CUO & 0.400 & 0.732 & & & & & & & & \\
\hline EA & 0.144 & 0.463 & 0.873 & & & & & & & \\
\hline EU & 0.077 & 0.284 & 0.353 & 0.738 & & & & & & \\
\hline FP & 0.246 & 0.435 & 0.526 & 0.275 & 0.838 & & & & & \\
\hline IFC & 0.451 & 0.664 & 0.431 & 0.373 & 0.406 & 0.719 & & & & \\
\hline IOP & 0.281 & 0.595 & 0.521 & 0.355 & 0.529 & 0.543 & 0.726 & & & \\
\hline NFP & 0.169 & 0.480 & 0.531 & 0.389 & 0.661 & 0.479 & 0.575 & 0.815 & & \\
\hline PUA & 0.300 & 0.460 & 0.476 & 0.244 & 0.319 & 0.502 & 0.643 & 0.426 & 0.714 & \\
\hline $\mathrm{TC}$ & 0.282 & 0.530 & 0.514 & 0.356 & 0.438 & 0.435 & 0.687 & 0.516 & 0.572 & 0.816 \\
\hline
\end{tabular}

TABLE 4. Loadings, Cronbach's Alpha, Composite Reliability and AVE for HOCs

\begin{tabular}{lcccc}
\hline Code & Loadings & $\begin{array}{c}\text { Cronbach's } \\
\text { Alpha }\end{array}$ & $\begin{array}{c}\text { Composite } \\
\text { Reliability }\end{array}$ & AVE \\
\hline ABC & & 0.841 & 0.893 & 0.678 \\
IOP & 0.881 & & & \\
PUA & 0.800 & & & \\
TC & 0.848 & & 0.907 & 0.830 \\
EA & 0.759 & & & \\
OP & & 0.796 & Nil & Nil \\
FB & 0.899 & & 0.855 & 0.667 \\
NFB & 0.923 & & & \\
EU & 1.000 & Nil & & \\
MO & & 0.754 & & \\
CUO & 0.892 & & & \\
COO & 0.637 & & & \\
IFC & 0.894 & & & \\
\hline
\end{tabular}

Table 5 presents the discriminant validity of the second-order model (HOCs), which is assessed with the square root of the AVE values, and it was expected to be higher than the correlations among latent constructs. The results of the discriminant validity show that the square root of the AVE values of each construct are all greater than the correlations among the constructs. Hence, this result indicates that there is a valid relationship between the first order dimensions and the second order variables.
TABLE 5. Discriminant validity for second stage hierarchical constructs model

\begin{tabular}{lcccc}
\hline Variables & ABC & EU & MO & OP \\
\hline ABC & $\mathbf{0 . 8 2 3}$ & & & \\
EU & 0.401 & $\mathbf{1 . 0 0 0}$ & & \\
MO & 0.648 & 0.330 & $\mathbf{0 . 8 1 7}$ & \\
OP & 0.652 & 0.368 & 0.525 & $\mathbf{0 . 9 1 1}$ \\
\hline
\end{tabular}

\section{STRUCTURAL MODEL}

In order to analyze the proposed hypotheses in this study, the PLS3-SEM was employed, using the bootstrap technique (Hair et al. 2014), to examine the direct relationship between external contingency factors, $\mathrm{ABC}$ implementation and organizational performance. As presented in Table 6, the results reveal that EU has a significant and positive effect on $\mathrm{ABC}$ implementation $(\beta=0.118, \mathrm{p}<0.05)$, and therefore $\mathrm{H}_{1}$ is supported. The results also demonstrate that $\mathrm{MO}$ has a positive and significant effect on $\mathrm{ABC}$ implementation $(\beta=0.352, \mathrm{p}<0.01)$. This provides the basis to support $\mathrm{H}_{2}$. The results also show that $\mathrm{ABC}$ implementation has a positive and significant effect on organizational performance $(\beta=0.347, p<0.01)$. Therefore, $\mathrm{H}_{3}$ is supported. However, the results show that $\mathrm{EU}(\beta=0.067, \mathrm{p}>0.10)$ and $\mathrm{MO}(\beta=0.022, \mathrm{p}>0.10)$ have no significant effect on organizational performance. Hence, $\mathrm{H}_{4}$ and $\mathrm{H}_{5}$ are not supported. 
TABLE 6. Structural model assessment

\begin{tabular}{lcccccc}
\hline $\mathrm{H}$ & Relationships & Beta & SE & t-values & p-values & Decisions \\
\hline $\mathrm{H}_{1}$ & $\mathrm{EU}>$ ABC & 0.118 & 0.069 & 1.699 & $0.045^{* *}$ & Supported \\
$\mathrm{H}_{2}$ & $\mathrm{MO}>$ ABC & 0.352 & 0.100 & 3.518 & $0.000^{* * *}$ & Supported \\
$\mathrm{H}_{3}$ & $\mathrm{ABC}->$ OP & 0.347 & 0.113 & 3.067 & $0.001^{* * *}$ & Supported \\
$\mathrm{H}_{4}$ & $\mathrm{EU}->$ OP & 0.067 & 0.083 & 0.809 & 0.209 & Not Supported \\
$\mathrm{H}_{5}$ & $\mathrm{MO}>$ OP & 0.022 & 0.097 & 0.230 & 0.409 & Not Supported \\
\hline Note: $* *: \mathrm{P}<0.05 ; * * *: \mathrm{P}<0.01$ & & & &
\end{tabular}

\section{TESTING MEDIATION EFFECT OF ABC IMPLEMENTATION}

The findings presented in Table 7 show that there is a mediation effect of $\mathrm{ABC}$ implementation on the relationship between $\mathrm{EU}$ and organizational performance $(\beta=0.041, t=1.383, p<0.10)$. Also, the mediating effect of $\mathrm{ABC}$ implementation on the relationship between $\mathrm{MO}$ and organizational performance was found to be significant $(\beta=0.122, t=2.523, p<0.01)$. In order to confirm the mediation effects of $\mathrm{ABC}$ implementation and for the assessment of hypotheses 6 and 7, the Variance Accounted For (VAF) was calculated. According to Hair et al. (2014), the VAF $=$ path $a^{*}$ path $\mathrm{b} /$ (path $\mathrm{c}+$ path $\mathrm{a}^{*}$ path $\mathrm{b}$ ) (See Figure 1). The ABC determines the size of the indirect effect about the total effect. Accordingly, the VAF is proposed as follows: $\mathrm{VAF}<20 \%=$ No Mediation; $20 \%>\mathrm{VAF}<80 \%$ $=$ Partial Mediation; VAF $>80 \%=$ Full Mediation. The VAF for the $\mathrm{H}_{6}$ is 0.379 , which therefore means there is a partial mediation. On this basis, $\mathrm{H}_{6}$ is supported. Finally, the VAF for $\mathrm{H}_{7}$ is 0.847 , which demonstrates full mediation. Hence, $\mathrm{H}_{7}$ is also supported.

TABLE 7. Testing the mediation effect of ABC implementation

\begin{tabular}{|c|c|c|c|c|c|c|c|c|}
\hline \multirow[b]{2}{*}{$\mathrm{H}$} & \multirow[b]{2}{*}{ Mediation Path } & \multirow[b]{2}{*}{ Beta } & \multirow[b]{2}{*}{$\mathrm{SE}$} & \multirow[b]{2}{*}{ t Value } & \multirow[b]{2}{*}{$\mathrm{p}$ Value } & \multicolumn{2}{|c|}{ Confidence Intervals } & \multirow[b]{2}{*}{ Decision } \\
\hline & & & & & & Lower Limit (5\%) & Upper Limit (95\%) & \\
\hline $\mathrm{H}_{6}$ & $\mathrm{EU}>\mathrm{ABC}>\mathrm{OP}$ & 0.041 & 0.030 & 1.383 & $0.084^{*}$ & 0.003 & 0.098 & Supported \\
\hline $\mathrm{H}_{7}^{\circ}$ & $\mathrm{MO}>\mathrm{ABC}>\mathrm{OP}$ & 0.122 & 0.048 & 2.523 & $0.006^{* * *}$ & 0.049 & 0.205 & Supported \\
\hline
\end{tabular}

Note: $*: \mathrm{p}<0.10 ; * * *: \mathrm{P}<0.01$

\section{FINDINGS AND DISCUSSIONS}

With regard to the first research objective, the results presented in Table 6 show that EU and MO have significant and positive effects on $\mathrm{ABC}$ implementation among manufacturing companies in Iraq. The results conform to the findings of previous $\mathrm{ABC}$ studies on the relationship between EU and $\mathrm{ABC}$ implementation (Arnaboldi \& Lapsley 2005; Innes \& Mitchell 1990; Elhamma 2015). From the perspective of MA studies, it is also evident that a higher level of uncertainty increases the need for sophisticated MA techniques to provide enhanced information, including cost information, to the individuals who then can take improved decisions and thus achieve the organizational goals in a better way (McManus 2013; Naranjo-Gil 2009). The findings of this study imply that, for organizations to be able to implement $\mathrm{ABC}$ successfully, they must take cognizant attention of their environment.

Furthermore, MO was also shown to play a significant role in enhancing the successful implementation of $\mathrm{ABC}$ among manufacturing companies in Iraq. The result suggests that organizations must pay attention to their markets regarding customers' demands, competitors' operations and inter-functional coordination. Hence, embracing a proactive culture in business operations to respond to market demands and expectations will enhance the successful implementation of $\mathrm{ABC}$. This result is consistent with the studies by Gliaubicas and Kanapickiene (2015), Yapa and Kongchan (2012) and Liu and $\mathrm{Pa}$ (2007), that an increase in competition and customer needs imply that the cost of mistakes is more readily exploited by competitors, precipitating the need for more accurate costing systems to minimize the level of organizational error.

Following the second objective of this study, which was to determine the effect of external contingency factors on organizational performance, the results demonstrate a nonsignificant effect of EU and MO on the performance of manufacturing companies in Iraq. This implies that managers' perception of EU has no significant effect on the performance of Iraqi manufacturing companies. It also means that information-related MO is not important to improving the performance of manufacturing companies. These results are inconsistent with previous studies. For instance, in spite of the significant number of studies such as Jusoh (2008), Mia and Clarke (1999), Uyar and Kuzey (2016), Low et al. (2007), which unanimously agreed that EU and MO are significantly associated with organizational performance, this study could not establish the proof of the connection between EU, MO 
and organizational performance among manufacturing organizations in Iraq.

Nonetheless, the findings of a non-significant association between external contingencies and organizational performance are consistent with the findings of Hoque (2004) and Han et al. (1998). Hoque (2004) found EU to be unassociated with organizational performance. He proved that MA information mediates this relationship. Han et al. (1998) found that the relationship between MO and organizational performance is positive but insignificant. They proved that technical and administrative innovations, in fact, mediate this relationship.

In addition, concerning the third research objective, the results of the current study reveal that $\mathrm{ABC}$ implementation has a positive and significant effect on organizational performance. The results are consistent with previous studies (Cagwin \& Bouwman 2002; Fei \& Isa 2011; Kennedy \& Affleck-Graves 2001; Lee et al. 2010; Maiga \& Jacobs 2003; Zaman 2009). This implies that manufacturing companies in Iraq are gaining the benefits of implementing $\mathrm{ABC}$ through the enhancement of their organizational performance.

Furthermore, with regards to the fourth research objective, the findings of this study affirm the mediation role of $\mathrm{ABC}$ implementation on the relationship between external contingencies and organizational performance. These findings imply that through the implementation of $\mathrm{ABC}$, the impacts of $\mathrm{EU}$ and $\mathrm{MO}$ on organizational performance become notable. However, Preacher and Hayes (2008) have argued that the significant effect of an independent variable on the dependent variable is not necessary for mediation to occur. This further justifies the insignificant relationship between external contingency factors and organizational performance. The findings of this study are consistent with the findings of Chong and Chong (1997) and Mia (1993), who found that EU has to be supported by appropriate MA information to achieve competitive advantage and ensure high performance.

In addition, the findings are also consistent with the findings of Mia and Clarke (1999), Han et al. (1998) and Hoque (2011), who reported that MO is a determinant of the use of the MA information (or innovations), and organizational performance is contingent on managers' use of this information or innovations. Therefore, the implementation of $\mathrm{ABC}$ will lessen the negative implications of the unpredictable environments on the performance of manufacturing companies. Also, the implementation of $\mathrm{ABC}$ in the manufacturing companies will fortify the positive implication of MO on their performances.

Overall, the findings of this study provide empirical evidence for the theoretical argument of the contingency theory, especially from the context of a developing and an Arab country. These findings indicate mixed implications, as the significant effects of external factors on $\mathrm{ABC}$ implementation and the significant effects of $\mathrm{ABC}$ implementation on organizational performance conform to the perspective of contingency theory on the one hand.
However, the insignificant effects of external factors on organisational performance defy the contingency theory on the other hand.

The findings reported in this study have significant theoretical implications. Chief among them is that the results of the present study provide the empirical evidence for the contingency theory, which proffers a cause-effect relationship or fit (Chenhall 2003) between contingency variables, cost control systems and organizational performance. Despite its importance, there is still scant research on $\mathrm{ABC}$ implementation in developing countries, especially in Iraq. In this regard, the results of this study contribute to a growing body of knowledge on external contingency variables, $\mathrm{ABC}$ implementation and organizational performance.

Most importantly, this study affirms the contingencybased "mediation" model by demonstrating the significant mediating effect of $\mathrm{ABC}$ implementation on the relationship between external contingency factors and organizational performance. In other words, this study evinced that the accurate information produced by $\mathrm{ABC}$ implementation enhances the effect of external contingency factors on organizational performance, which is consistent with Gerdin and Greve's (2004) "mediation" model of the Cartesian-contingency approach. Also, the results are consistent with the view put forward by previous MA researchers (e.g. Cagwin \& Bouwman 2002; Chong \& Chong 1997; Han et al. 1998; Hoque 2011; Ismail \& Isa 2011; Mia 1993; Mia \& Clarke 1999) that the more the contingencies, the higher the need for sophisticated MA that can provide managers with high quality information in order to make reasonable and accurate decisions, so that organizations can enhance their overall goals.

The present study also makes some critical practical contributions about implementing $\mathrm{ABC}$ and improving organizational performance. This research supports that the implementation of $\mathrm{ABC}$ systems among manufacturing companies in Iraq be closely associated to contingency factors such as EU and MO. The non-financial, as well as financial benefits of $\mathrm{ABC}$ systems, will allow the manufacturing decision makers and managers to make successful decisions, which in turn improve the financial and non-financial performance of Iraqi manufacturing companies. Practically, this finding is a crucial contribution to the $\mathrm{ABC}$ literature. It suggests that $\mathrm{ABC}$ implementation has the characteristics of any information system, which covers information and details relating to the external environment of the company. In other words, EU and MO are very important sources of information to increase the level of implementation of $\mathrm{ABC}$, which in turn uses this information to achieve a high level of organizational performance.

\section{CONCLUSION}

This study reports that EU and MO are significant factors for enhancing the successful implementation of $\mathrm{ABC}$ 
among manufacturing companies in Iraq. Also, $\mathrm{ABC}$ implementation demonstrates a positive and significant role in the improvement of organizational performance. Furthermore, the mediation effect of $\mathrm{ABC}$ implementation on the relationships between $\mathrm{EU}$ and $\mathrm{MO}$ on organizational performance demonstrates that manufacturing companies in Iraq have the opportunity to enhance their performance through the implementation of $\mathrm{ABC}$. However, this study failed to support a significant relationship between EU, MO and organizational performance.

Like every academic research, this study is not without its peculiar limitations. One of the limitations of this research is that it relies only on the primary source of data gathered through a cross-sectional approach. Therefore, future researchers might consider a longitudinal research design, whereby financial and non-financial indices of organizations before and after the implementation of $\mathrm{ABC}$ can be compared to further elaborate on the effect of external contingency factors on $\mathrm{ABC}$ and organizational performance.

Although an attempt was made to reduce common method variance by ensuring anonymity and improving scale items, the possibility that participants in this study might have under-or over-reported their rate of $\mathrm{ABC}$ implementation and organizational performance in the questionnaire cannot be ignored. In addition, the research is limited to the Cartesian type of contingency approach. For future research, it is recommended to examine the mediating effect of $\mathrm{ABC}$ implementation on the relationship between multiple contingency factors and organizational performance under the Configuration type of contingency approach. At the empirical level, the study is limited to the large manufacturing companies in Iraq. Therefore, the results may not be generalizable to small and medium-sized companies and other sectors. Future studies may replicate this study in other sectors and in small and medium-sized companies.

\section{REFERENCES}

Abdel-Kader, M. \& Luther, R. 2008. The impact of firm characteristics on management accounting practices: A UK-based empirical analysis. The British Accounting Review 40(1): 2-27.

Ajibolade, S. 2013. Management accounting systems design and company performance in Nigerian manufacturing companies: A contingency theory perspective. British Journal of Arts and Social Sciences 14(2): 228-244.

Al-Zaidy, M.F. 2010. The challenges facing the application of modern management accounting techniques studying for the opinion a sample of accountants in the city of mosul. Tanmiat Al-Rafidain 32(97): 311-334.

Anderson, S.W. \& Young, S.M. 1999. The impact of contextual and process factors on the evaluation of activity-based costing systems. Accounting, Organizations and Society 24(7): 525-559.

Arnaboldi, M. \& Lapsley, I. 2005. Activity-based costing in healthcare: A UK case study. Research in Healthcare Financial Management 10(1): 61.
Baines, A. \& Langfield-Smith, K. 2003. Antecedents to management accounting change: A structural equation approach. Accounting, Organizations and Society 28(7): 675-698.

Bromwich, M. 1990. The case for strategic management accounting: The role of accounting information for strategy in competitive markets. Accounting, Organizations and Society 15(1-2): 27-46.

Buchko, A.A. 1994. Conceptualization and measurement of environmental uncertainty: An assessment of the Miles and Snow perceived environmental uncertainty scale. Academy of Management Journal 37(2): 410-425.

Byrne, S. 2011. What determines ABC success in mature sites?. Journal of Accounting \& Organizational Change 7(3): 259-277.

Cadez, S. \& Guilding, C. 2008. An exploratory investigation of an integrated contingency model of strategic management accounting. Accounting, Organizations and Society 33(7): 836-863.

Cagwin, D. \& Bouwman, M.J. 2002. The association between activity-based costing and improvement in financial performance. Management Accounting Research 13(1): $1-39$.

Cescon, F., Costantini, A. \& Grassetti, L. 2018. Strategic choices and strategic management accounting in large manufacturing firms. Journal of Management and Governance: 1-32.

Chenhall, R.H. 2003. Management control systems design within its organizational context: Findings from contingencybased research and directions for the future. Accounting, Organizations and Society 28(2): 127-168.

Chenhall, R.H. \& Langfield-Smith, K. 1998. The relationship between strategic priorities, management techniques and management accounting: An empirical investigation using a systems approach. Accounting, Organizations and Society 23(3): 243-264.

Chenhall, R.H. \& Morris, D. 1986. The impact of structure, environment, and interdependence on the perceived usefulness of management accounting systems. Accounting Review 61: 16-35.

Chin, W.W. 1998. The partial least squares approach to structural equation modeling. Modern Methods for Business Research 295(2): 295-336.

Chong, V.K. \& Chong, K.M. 1997. Strategic choices, environmental uncertainty and SBU performance: A note on the intervening role of management accounting systems. Accounting and Business Research 27(4): 268-276.

Cinquini, L., Collini, P., Marelli, A. \& Tenucci, A. 2015. Change in the relevance of cost information and costing systems: Evidence from two Italian surveys. Journal of Management \& Governance 19(3): 557-587.

Creswell, J.W. 2009. Qualitative, Quantitative, and Mixed Methods Approaches. London: Sage Publications.

CSO. 2015. Statistics of large industrial installations (cumulative) annual 2015. Available at http://www.cosit.gov.iq.

Day, G.S. \& Wensley, R. 1988. Assessing advantage: A framework for diagnosing competitive superiority. The Journal of Marketing 55(2): 1-20.

Elhamma, A. 2015. The relationship between activity based costing, perceived environmental uncertainty and global performance. International Journal of Management, Accounting and Economics 2(1): 73-90. 
Farhood, S.B. 2005. Influence of using activity based costing system in evaluation of performance efficincy. Foundation of Technical Education 18(4): 70-88.

Fei, Z.Y. \& Isa, C.R. 2011. The effect of activity-based costing on firms performance: A study among Chinese manufacturing firms. Australian Journal of Basic and Applied Sciences 5(9): 227-237.

Fornell, C. \& Larcker, D.F. 1981. Structural equation models with unobservable variables and measurement error: Algebra and statistics. Journal of Marketing Research 18(1): 382-388.

Frazier, P.A., Tix, A.P. \& Barron, K.E. 2004. Testing moderator and mediator effects in counseling psychology research. Journal of Counseling Psychology 51(1): 115-134.

Frey, K. \& Gordon, L.A. 1999. ABC, strategy and business unit performance. International Journal of Applied Quality Management 2(1): 1-23.

Gerdin, J. \& Greve, J. 2004. Forms of contingency fit in management accounting research-A critical review. Accounting, Organizations and Society 29(3): 303-326.

Gliaubicas, D. \& Kanapickienė, R. 2015. Contingencies impact on strategic cost management usage in Lithuanian companies. Procedia-Social and Behavioral Sciences 213: 254-260.

Govindarajan, V. 1984. Appropriateness of accounting data in performance evaluation: An empirical examination of environmental uncertainty as an intervening variable. Accounting, Organizations and Society 9(2): 125-135.

Guilding, C. \& McManus, L. 2002. The incidence, perceived merit and antecedents of customer accounting: An exploratory note. Accounting, Organizations and Society 27(1): 45-59.

Gupta, M. \& Galloway, K. 2003. Activity-based costing/ management and its implications for operations management. Technovation 23(2): 131-138.

Hair, J.F., Sarstedt, M., Hopkins, L. \& Kuppelwieser, V.G. 2014. Partial least squares structural equation modeling (PLSSEM): An emerging tool in business research. European Business Review 26(2): 106-121.

Han, J.K., Kim, N. \& Srivastava, R.K. 1998. Market orientation and organizational performance: Is innovation a missing link? The Journal of Marketing 62(4): 30-45.

Henseler, J. 2007. A new and simple approach to multi-group analysis in partial least squares path modeling. Proceedings of PLS'07 - The 5th International Symposium on PLS and Related Methods, edited by H. Martens \& T. Naes, 104107. PLS.

Hoque, Z. 2004. A contingency model of the association between strategy, environmental uncertainty and performance measurement: Impact on organizational performance. International Business Review 13(4): 485-502.

Hoque, Z. 2011. The relations among competition, delegation, management accounting systems change and performance: A path model. Advances in Accounting 27(2): 266-277.

Hunt, S.D. \& Lambe, C.J. 2000. Marketing's contribution to business strategy: Market orientation, relationship marketing and resource-advantage theory. International Journal of Management Reviews 2(1): 17-43.

Innes, J. \& Mitchell, F. 1990. The process of change in management accounting: Some field study evidence. Management Accounting Research 1(1): 3-19.

Ismail, K., Isa, C.R. \& Mia, L. 2018a. Evidence on the usefulness of management accounting systems in integrated manufacturing environment. Pacific Accounting Review 30(1): 2-19.
Ismail, K., Isa, C.R. \& Mia, L. 2018b. Market competition, lean manufacturing practices and the role of management accounting systems (MAS) information. Jurnal Pengurusan 52: 47-61.

Ittner, C.D., Lanen, W.N. \& Larcker, D.F. 2002. The association between activity-based costing and manufacturing performance. Journal of Accounting Research 40(3): 711-726.

Jaf, R.A., Sabr, S.A. \& Nader, K.A. 2015. Impact of management accounting techniques on achieve competitive advantage. Research Journal of Finance and Accounting 6(4): 8499.

Jänkälä, S. \& Silvola, H. 2012. Lagging effects of the use of activity-based costing on the financial performance of small firms. Journal of Small Business Management 50(3): 498-523.

Juhdi, N.H., Hong, T.S. \& Juhdi, N. 2015. Market orientation and entrepreneurial success: Mediating role of entrepreneurial learning intensity. Jurnal Pengurusan 43: 27-36.

Jusoh, R. 2008. Environmental uncertainty, performance, and the mediating role of balanced scorecard measures use: Evidence from Malaysia. International Review of Business Research Papers 4(2): 116-135.

Jusoh, R. \& Miryazdi, S. 2015. The influence of technological and environmental factors on the diffusion of activity-based costing in Iran. Tékhne 13(2): 95-109.

Kalkan, A., Erdil, O. \& Çetinkaya, Ö. 2011. The relationships between firm size, prospector strategy, architecture of information technology and firm performance. ProcediaSocial and Behavioral Sciences 24: 854-869.

Kaplan, R.S. 2001. Strategic performance measurement and management in nonprofit organizations. Nonprofit Management and Leadership 11(3): 353-370.

Kennedy, T. \& Affleck-Graves, J. 2001. The impact of activitybased costing techniques on firm performance. Journal of Management Accounting Research 13(1): 19-45.

Köseoglu, M.A., Topaloglu, C., Parnell, J.A. \& Lester, D.L. 2013. Linkages among business strategy, uncertainty and performance in the hospitality industry: Evidence from an emerging economy. International Journal of Hospitality Management 34: 81-91.

Kotha, S. \& Nair, A. 1995. Strategy and environment as determinants of performance: Evidence from the Japanese machine tool industry. Strategic Management Journal 16(7): 497-518.

Krejcie, R.V. \& Morgan, D.W. 1970. Determining sample size for research activities. Educ Psychol Meas 30: 607-610.

Laitinen, E.K. 2014. Influence of cost accounting change on performance of manufacturing firms. Advances in Accounting 30(1): 230-240.

Lee, C.L., Yen, D.C., Peng, K.C. \& Wu, H.C. 2010. The influence of change agents' behavioral intention on the usage of the activity based costing/management system and firm performance: The perspective of unified theory of acceptance and use of technology. Advances in Accounting 26(2): 314-324.

Liu, L.Y. \& Pan, F. 2007. The implementation of activity-based costing in china: An innovation action research approach. The British Accounting Review 39(3): 249-264.

Lohmöller, J.B. 1989. Latent Variable Path Modeling with Partial Least Squares. New York: Springer Science \& Business Media. 
Low, D.R., Chapman, R.L. \& Sloan, T.R. 2007. Interrelationships between innovation and market orientation in SMEs. Management Research News 30(12): 878-891.

Lu, T.Y., Wang, S.L., Wu, M.F. \& Cheng, F.T. 2017. Competitive price strategy with activity-based costing-Case study of bicycle part company. Procedia CIRP 63: 14-20.

Maiga, A.S. \& Jacobs, F.A. 2003. Balanced scorecard, activitybased costing and company performance: An empirical analysis. Journal of Managerial Issues 15(3): 283-301.

Maiga, A.S., Nilsson, A. \& Jacobs, F.A. 2013. Assessing the interaction effect of cost control systems and information technology integration on manufacturing plant financial performance. The British Accounting Review 30: 1-14.

Mat, T.Z. \& Smith, M. 2014. The impact of changes in environment and AMT on management accounting practices and organizational strategy, structure and performance. Journal of Applied Management Accounting Research 12(1): 55-82.

McGowan, A.S. 1998. Perceived benefits of ABCM implementation. Accounting horizons 12(1): 31.

McManus, L. 2013. Customer accounting and marketing performance measures in the hotel industry: Evidence from Australia. International Journal of Hospitality Management 33: $140-152$.

Mia, L. 1993. The role of mas information in organisations: An empirical study. The British Accounting Review 25(3): 269-285.

Mia, L. \& Clarke, B. 1999. Market competition, management accounting systems and business unit performance. Management Accounting Research 10(2): 137-158.

Naranjo-Gil, D. 2009. The influence of environmental and organizational factors on innovation adoptions: Consequences for performance in public sector organizations. Technovation 29(12): 810-818.

Narver, J.C. \& Slater, S.F. 1990. The effect of a market orientation on business profitability. The Journal of Marketing 20-35.

Noble, C.H., Sinha, R.K. \& Kumar, A. 2002. Market orientation and alternative strategic orientations: A longitudinal assessment of performance implications. Journal of Marketing 66(4): 25-39.

O'Cass, A. \& Viet Ngo, L. 2007. Market orientation versus innovative culture: Two routes to superior brand performance. European Journal of Marketing 41(7/8): 868-887.

Preacher, K.J. \& Hayes, A.F. 2008. Asymptotic and resampling strategies for assessing and comparing indirect effects in multiple mediator models. Behavior Research Methods 40(3): 879-891.

Qian, L. \& Ben-Arieh, D. 2008. Parametric cost estimation based on activity-based costing: A case study for design and development of rotational parts. International Journal of Production Economics 113(2): 805-818.

Rahmouni, A.F.A. \& Charaf, K. 2010. Success of activity-based costing projects in French companies: The influence of organizational and technical factors. Journal of Cost Management 26(6): 1-27.

Rivard, S., Raymond, L. \& Verreault, D. 2006. Resource-based view and competitive strategy: An integrated model of the contribution of information technology to firm performance. The Journal of Strategic Information Systems 15(1): 2950.
Slater, S.F. \& Narver, J.C. 2000. The positive effect of a market orientation on business profitability: A balanced replication. Journal of Business Research 48(1): 69-73.

Soheilirad, S. \& Sofian, S. 2016. A proposed model of the mediating effect of strategic management accounting on the relationship between perceived environmental uncertainty and firm performance. International Journal of Research 4(1): 231-239.

Sorros, J., Karagiorgos, A. \& Mpelesis, N. 2017. Adoption of activity-based costing: A survey of the education sector of Greece. International Advances in Economic Research 23(3): 309-320.

Tillema, S. 2005. Towards an integrated contingency framework for MAS sophistication: Case studies on the scope of accounting instruments in Dutch power and gas companies. Management Accounting Research 16(1): 101-129.

Uyar, A. \& Kuzey, C. 2016. Contingent factors, extent of budget use and performance: A structural equation approach. Australian Accounting Review 26(1): 91-106.

Yapa, P. \& Kongchan, P. 2012. Factors influencing the implementation of activity-based costing in Thailand: A case study of a Thai telecommunications company. Proceedings of Accounting and Finance Association of Australia and New Zealand Conference (AFAANZ 2012), 1-3 July. Carlton, Australia, 1-30.

Yaqoob, F.B \& Bachay, A.R. 2017. Designing activity based costing systems $(\mathrm{ABC})$ for transport services and its role in improving the efficiency of pricing decisions. Accounting and Financial Studies Journal 12(41): 1-27

Youssef, Z.J. \& Oudah, H.A. 2014. The importance of activitybased costing system in the administrative decisions (case study). Journal of Babylon University 22(4): 932-945.

Zaman, M. 2009. The Impact of activity based costing on firm performance: The Australian experience. International Review of Business Research Papers 5(4): 200-208.

Zhang, Y.F., Hoque, Z. \& Isa, C.R. 2015. The effects of organizational culture and structure on the success of activity-based costing implementation. Advances in Management Accounting 25: 229-257.

Zhou, K.Z., Brown, J.R. \& Dev, C.S. 2009. Market orientation, competitive advantage, and performance: A demand-based perspective. Journal of Business Research 62(11): 10631070.

Faeq Malallah Mahmood Albalaki (corresponding author) Department of Accounting

College of Administration and Economics

Mosul University, Mosul, IRAQ.

E-Mail: faeq_mahmood@yahoo.com

Zarifah Abdullah

Tunku Puteri Intan Safinaz School of Accountancy

Universiti Utara Malaysia

06010 UUM Sintok, Kedah, MALAYSIA.

E-Mail: zarifah@uum.edu.my

Hasnah Kamardin

Tunku Puteri Intan Safinaz School of Accountancy

Universiti Utara Malaysia

06010 UUM Sintok, Kedah, MALAYSIA.

E-Mail: hasnahk@uum.edu.my 